\title{
The use of contraception for patients after bariatric surgery
}

\author{
Lucyna Ostrowska ${ }^{1}$, Medard Lech ${ }^{2}$, Ewa Stefańska ${ }^{1}$, Marta Jastrzębska-Mierzyńska ${ }^{1}$, \\ Joanna Smarkusz ${ }^{1}$ \\ ${ }^{1}$ Department of Dietetics and Clinical Nutrition, Medical University, Bialystok, Poland \\ ${ }^{2}$ Fertility and Sterility Research Centre, Warsaw, Poland
}

\begin{abstract}
Obesity in women of reproductive age is a serious concern regarding reproductive health. In many cases of infertility in obese women, reduction of body weight may lead to spontaneous pregnancy, without the need for more specific methods of treatment. Bariatric surgery is safe and is the most effective method for body weight reduction in obese and very obese patients. In practice there are two bariatric techniques; gastric banding, which leads to weight loss through intake restriction, and gastric bypass, leads to weight loss through food malabsorption. Gastric bypass surgery (the more frequently performed procedure), in most cases, leads to changes in eating habits and may result in vomiting, diarrhea and rapid body mass reduction. There are reliable data describing the continuous increase in the number of women who are trying to conceive, or are already pregnant, following bariatric surgery. Most medical specialists advise women to avoid pregnancy within 12-18 months after bariatric surgery. This allows for time to recover sufficiency from the decreased absorption of nutrients caused by the bariatric surgery. During this period there is a need for the use of reliable contraception. As there is a risk for malabsorption of hormones taken orally, the combined and progestogen-only pills are contraindicated, and displaced by non-oral hormonal contraception or non-hormonal methods, including intrauterine devices and condoms.
\end{abstract} Key words: obesity, operative techniques, bariatrics, contraceptive methods, hormones

Ginekologia Polska 2016; 87, 8: 591-593

\section{INTRODUCTION}

Based on research from 2003-2005, it can be assumed that more than $20 \%$ of Polish women suffer from obesity, and $2.2 \%$ of women very severe obesity [body mass index (BMI) $>40 \mathrm{~kg} / \mathrm{m}^{2}$ ] [1]. Data from 2009 in Poland, in women aged over 15 years, has suggested that $15.2 \%$ of women were obese and $29.4 \%$ of women were overweight [2]. Higher percentages of obesity and overweight among women have been observed in studies from 2014 [3]. There are no significant, numerical data regarding the prevalence of obesity for women in their reproductive years, but obesity almost certainly affects this population to a significant level. It is considered that obesity is one of the factors that prevents or hinders pregnancy, while it is associated with an unhappy motherhood in women who do achieve pregnancy [4-6]. Over $20 \%$ of couples in Europe wishing to conceive a child, need to use a form of assisted reproduction [6]. The first recommendation following consultation with a reproductive specialist in the clinic is typically weight reduction [7]. In some instances, weight loss alone results in the restoration of regular menstrual cycles and successful pregnancy. Medical literature and popular magazines provide a lot of information about weight loss methods. These methods are associated with good results in a proportion of patents. However, for most women with obesity or very severe obesity, conventional methods of weight reduction are usually unsatisfactory or ineffective. This is the reason why obese women, especially women with problems getting pregnant, decide to have bariatric surgery. Every type of bariatric surgery has its own characteristics and aims to reduce the absorption of nutrients. Weight reduction in obese women is expected, although limiting the absorption of some nutrients, supplements and vitamins prior to pregnancy (or during pregnancy) may have a negative effect on the pregnancy, affecting the 
development of the fetus and newborn. Accordingly, it is recommended that women should postpone pregnancy by at least 12 to 18 months following bariatric surgery $[8,9]$.

If correctional methods of weight reduction are ineffective, bariatric surgery is available.

Bariatric surgery leads to good results in weight reduction in very obese women, and contributes to the reduction of the risk of complications such as: gestational diabetes, hypertension, pre-eclampsia, eclampsia, thrombosis, intrauterine infections, abnormal fetal development, miscarriage or premature births, malformations, and even excessive risk of infant death [10]. Furthermore, many women also get the chance to become pregnant naturally. In the United States in 1998-2005, among patients aged 18-45 years who had undergone bariatric methods, up to $83 \%$ were women [11, 12]. In the years 2005-2013 in Germany, 10,330 bariatric procedures were performed, with $80 \%$ of procedures performed in women [13]. According to epidemiological data from Brazil [14], where bariatric surgery is very popular, $78 \%$ of all bariatric procedures were performed in women, and the average age of patients was 37 years old. Similar demographic data has emerged from an analysis of more than 810,000 bariatric procedures, performed in the United States between 20022011 [15], and analysis of 3,039 bariatric surgeries performed in the United Kingdom between 2002-2014 [16].

Surgeons utilise various techniques to perform bariatric surgery, although the ultimate goal is to achieve weight loss as a result of intake restriction or reduced absorption of nutrients (food malabsorption) $[17,18]$. Techniques based on both of these mechanisms are also available. Treatment approaches involving food intake restriction utilise adjustable gastric bands or sleeve gastrectomy. For the second group of treatment approaches (excluding treatments), the biliary limb, pancreas and duodenum are excluded. The third group (the treatment combining both of these methods) includes completion of Roux-en-Y gastric bypass surgery. Restrictive procedures, which reduce stomach capacity and narrow the passage of food into the intestine, limit servings of food consumed. Excluding treatments, restricting surface absorption in the gastrointestinal tract and reducing the transit time of food, reduce the absorption of nutrients (especially excess carbohydrates and fats). Until recently, there were no serious complications reported in the fetus and infants born to women after bariatric surgery. However, some data show cases of abnormalities resulting from neural tube defects, low birth weight, and even rickets in children born to women shortly after bariatric surgery [19]. It is generally assumed that there is no difference between pregnancy outcome and parameters of infants born to women becoming pregnant in the first or second year following surgery, but the majority of specialists in bariatric surgery maintain that in the period of 12-18 months after surgery (it is believed that this is a period of fairly rapid loss of body weight) women should avoid becoming pregnant $[8,9,19-21]$. It is very important for women planning pregnancy or during pregnancy to ensure suitable supplementation of iron, vitamin $D$, calcium, folic acid and vitamin B12 [22-24]. Two of the most important laboratory tests, frequently used in obese women, are tests for glucose intolerance and diabetes. The results of these tests in women after bariatric surgery, in particular the glucose tolerance test, may be misinterpreted or could lead to erroneous findings. The reason for this relates specifically to patients after Roux-en-Y gastric bypass surgery, as these patients experience a dumping syndrome (symptoms like vomiting, bloating, sweating, dizziness, palpitations, and sometimes diarrhea), which may distort the results of the glucose tolerance test. In such cases, only fasting glucose or the concentration of glycated hemoglobin, should be tested.

\section{CONTRACEPTION AND OBESITY}

According to medical criteria for the selection of contraceptive methods [25], obesity does not exclude the use of any form of contraception. Only using the combined pill raises some issues due to a slight increase in the risk of thrombotic complications of obese women (BMI $\left.\geq 30 \mathrm{~kg} / \mathrm{m}^{2}\right)$, compared with obese women not using the combined pill. The European Society of Contraception [26] advises that even women after bariatric surgery (without exclusion or combined surgery) can safely use combined pills, and patients treated by restrictive methods, after reaching a $\mathrm{BMI}<30 \mathrm{~kg} / \mathrm{m}^{2}$, should not use oral combined pills. However, there is limited evidence that hormonal contraception is less effective in obese women compared to women with normal body weight. However, there are exceptions to this rule. One of them is the use of contraceptive patches that contain ethinyl estradiol and norelgestromin [27]. It is believed that the effectiveness of this form of contraception may be reduced in women weighing $\geq 90 \mathrm{~kg}$. At present, there are no data on the effectiveness of the contraceptive patch, containing $0.55 \mathrm{mg}$ ethinyl estradiol and $2.1 \mathrm{mg}$ gestodene in obese women [28]. However, there are still quite limited data on the efficacy of this form of contraceptive, in women with $\mathrm{BMI} \geq 30 \mathrm{~kg} / \mathrm{m}^{2}$ [29]. Another exception is the use of emergency contraception by obese patients, especially those that contain $1.5 \mathrm{mg}$ levonorgestrel [30]. In the literature there are also some reservations about the effectiveness of the progestogen-only pill in obese women [31], although poor adherence may have been the cause of reduced efficacy of this method.

\section{HORMONAL CONTRACEPTION FOR WOMEN AFTER EXCLUSION OR MIXED BARIATRIC SURGERY}

As seen in Table 1, neither combination nor progestogen-only pills should be used in patients after the more 
Table 1. Proposed medical criteria for the selection of contraception in obese patients and patients following bariatric surgery

\begin{tabular}{|l|c|c|}
\hline \multirow{2}{*}{ Type of contraceptive } & \multicolumn{2}{|c}{ Recommendations for patients } \\
\cline { 2 - 3 } & $\begin{array}{c}\text { Obese [25] or after bariatric surgery } \\
\text { (no malabsorption) }\end{array}$ & After bariatric surgery with malabsorption \\
\hline Contraceptive implant & No contraindications & No contraindications \\
\hline Medroxyprogesterone in injections & No contraindications & No contraindications \\
\hline Contraceptive patches and rings & No contraindications & No contraindications \\
\hline Combination pills & Used with caution & Method not recommended unless others cannot be used \\
\hline Progestogen-only pills & No contraindications & Method not recommended unless others cannot be used \\
\hline Emergency contraception & No contraindications & Method not recommended unless others cannot be used \\
\hline IUD (Intra Uterine Device) & No contraindications & No contraindications
\end{tabular}

radical (impairing absorption) bariatric surgery. For these patients, emergency contraception pills are also not recommended. Other methods can be offered for these patients, including hormonal contraception in injection, implants, rings or patches. Although the treatment of patients after bariatric surgery is not performed by gynaecologists, knowledge of the proper selection of contraceptive methods is useful for specialists in this field [32]. Furthermore, it is important that contraception is available to all patients after bariatric surgery, and that for women planning pregnancy, periodic contraception is indicated for the health of the fetus and newborn.

\section{REFERENCES}

1. Biela U, Pająk A, Kaczmarczyk-Chałas K, Głuszek J, [et al.]. Częstość występowania nadwagi i otyłości u kobiet i mężczyzn w wieku 20-74 lat. Wyniki programu WOBASZ. Kardiol Pol 2005, 63 (suppl. 4), 632-635.

2. Urząd Statystyczny w Krakowie, Zdrowie Kobiet w Polsce w latach 2004-2009, Studia i Analizy Statystyczne, Kraków 2012.

3. EHIS-2014; Ankietowe Badanie Zdrowia i Zachowań Zdrowotnych Mieszkańców Polski, http://stat.gov.pl/obszary-tematyczne/zdrowie.

4. Kanadys WM, Oleszczuk J. Otyłość jako położniczy czynnik ryzyka, Gin Pol. 1999, 70, 464-70.

5. Hajduk M. Wpływ masy ciała na płodność kobiet. Endokrynologia, Otyłość i Zaburzenia Przemiany Materii 2012, 8, 93-97.

6. Jungheim ES, Travieso JL, Carson KR, Moley KH. Obesity and reproductive function, Obstet Gynecol Clin North Am. 2012, 39, 479-493.

7. Schmidt L. Infertility and assisted reproduction in Denmark. Epidemiology and psychosocial consequences. Dan Med Bull. 2006, 53, 390-417.

8. American College of Obstetricians and Gynecologists (ACOG). ACOG practice bulletin: bariatric surgery and pregnancy 105. Obstet Gynecol. 2009, 1134, 1405-1413.

9. Manning S, Finer N, Elkalaawy M, [et al.]. Timing of pregnancy in obese women after bariatric surgery. Pregnancy Hypertens. 2014, 4, 235.

10. Garcia J, High Prepregnancy BMI Increases Risk for Infant Mortality, Obstet Gynecol. 2016, 127, 279-287.

11. Yermilov I, McGory ML, Shekelle PW, [et al.]. Appropriateness criteria for bariatric surgery: beyond the NIH guidelines. Obesity (Silver Spring). 2009, 17, 1521-1527.

12. Shekelle PG, Newberry S, Maglione M, [et al.]. Bariatric surgery in women of reproductive age: special concerns for pregnancy. Evid Rep Technol Assess. 2008, 169, 1-51.

13. Stroh $C$, Weiner $R$, Wolff $S$, [et al.]. Influence of gender on complication rate and outcome after Roux-en-Y gastric bypass: data analysis of more than 10,000 operations from the German Bariatric Surgery Registry. Obes Surg. 2014, 24, 1625-1633.

14. Silva PT, Patias LD, Alvarez Gda C, [et al.]. Profile of Patients who Seek the Bariatric Surgery. Arg Bras Cir Dig. 2015, 28, 270-273.
15. Young MT, Phelan MJ, Hguyen NT. A Decade Analysis of Trends and Outcomes of Male vs Female Patients Who Underwent Bariatric Surgery. J Am CollSurg. 2015, Dec 17, S1072-7515(15)01771-8.

16. Booth HP, Khan O, Fildes A, [et al.]. Changing Epidemiology of Bariatric Surgery in the UK: Cohort Study Using Primary care Electronic Health Records. Obes Surg. 2016, Jan 12.

17. Kral JG. Surgical treatment of obesity. Med Clin North Am. 1989, 73, 251-264.

18. Dadan J, Iwacewicz P, Razak H, [et al.]. Wstępne wyniki chirurgicznego leczenia otyłości metodą regulowanej opaski żołądkowej i zespolenia omijającego żołądkowo-jelitowego z pętlą Rouxen-Y. Pol Merk Lek. $2007,23,344-347$.

19. Hezelgrave NL, Oteng-Ntim E. Pregnancy after bariatric surgery. J Obes. 2011, 2011, 501939.

20. Sheiner E, Edri A, Balaban E, [et al.]. Pregnancy outcomes of patients who conceive during or after the first year following bariatric surgery. Am J Obstet Gynecol. 2011, 204: 50, e1-6.

21. Khan R, Dawlatly B, Chappatte O. Pregnancy outcome following bariatric surgery. Obstet Gynaecol. 2013, 15, 37-43.

22. Kanadys WM, Leszczyńska-Gorzelak B, Oleszczuk J. Otyłość u kobiet. Ciąża po operacji bariatrycznej - przegląd jakościowy. Gin Pol. 2010, $81,215-223$.

23. Jastrzębska M, Ostrowska L. Zalecenia dietetyczne po zabiegach bariatrycznych. Forum Zab Metab. 2010, 1, 201-209.

24. Jeznach-Steinhagen A, Bień K. Zalecenia dietetyczne dla osób po operacjach bariatrycznych. Med Metabol. 2007, 11, 81-85.

25. WHO Medical Eligibility Criteria for Contraceptive Use. 5th Edition, 2004 and its 2015 update, http://www.who.int/reproductivehealth/topics/family_planning/en

26. Merki-Feld GS, Skouby S, Serfaty D, [et al.]. Consensus Opinion, European Society of Contraception Statement on Contraception in Obese Women, Eur J Contracept Reprod Health Care. 2015, 20, 19-28.

27. Zieman M, Guillebaud J, Weisberg E, [et al.]. Contraceptive efficacy and cycle control with the Ortho Evra/Evra transdermal system; The analysis of pooled data. Fertil Steril 2002, 77, S13-18.

28. Hofmann B, Reinecke I, Schuett B, [et al.]. Pharmacokinetic overview of ethinyl estradiol dose and bioavailability using two transdermal contraceptive systems and standard combined oral contraceptive. Int J Clin Pharmoacol Ther. 2014, 52, 1059-1070.

29. Westhoff CL, Reinecke I, Bangerter K, Merz M. Impact of body mass index on suppression of follicular development and ovulation using a transdermal patch containing $0.55-\mathrm{mg}$ ethinyl estradiol $/ 2,1 \mathrm{mg}$ gestodene: a multicenter, open-label, uncontrolled study over three treatment cycles. Contraception. 2014, 90, 27-79.

30. Glasier A, Cameron ST, Blithe D, [et al.]. Can we identify women at risk of pregnancy despite using emergency contraception? Data from randomized trials of ulipristal acetate and levonorgestrel. Contraception. 2011, 82, 86-94.

31. Chandler J, Nash K. Contraceptive failure and the progestogen-only pill: the issue of body weight. J Fam Plann Reprod Health Care 2010, 36, 167-168.

32. Jatlaoui TC, Cordes S, Goedken $\mathrm{P}$, [et al.]. Family planning knowledge, attitudes and practices among bariatric healthcare providers. Contraception. 2016, Jan 5.pii:S0010-7824(15)00707-6. 